\title{
Attitude Determinant in Entrepreneurship Behavior of Vocational Student's Entrepreneurship Intention
}

\author{
Ludi Wishnu Wardana \\ Departement of Management, Universitas Negeri Malang \\ Email: ludi.wishnu.fe@um.ac.id
}

\begin{abstract}
This present study was aimed at finding out the correlation of emotional intelligence, entrepreneurship self-efficacy, entrepreneurship behavioral attitude and entrepreneurship intention on vocational school students. The data were analyzed using SEM Smart PLS technique. The study revealed that there is a cause and effect correlation of emotional intelligence and entrepreneurship self-efficacy, entrepreneurship behavioral attitude toward entrepreneurship intention on vocational students in Mojokerto regency as described: 1) empirically, emotional intelligence was proven to have no direct influence on entrepreneurship intention, however, it has direct and strong influence on entrepreneurship behavioral attitude, 2) entrepreneurship self-efficacy has direct and strong influence on entrepreneurship behavioral attitude and entrepreneurship intention, and entrepreneurship self-efficacy also has indirect influence toward the entrepreneurship intention through entrepreneurship behavioral attitude, 3) entrepreneurship behavioral attitude has direct and strong influence toward entrepreneurship intention.
\end{abstract}

Keywords: emotional intelligence, entrepreneurship, behavioral attitude, entrepreneurship intention.

\section{INTRODUCTION}

As competition in finding jobs become more demanding, Indonesian youth, especially vocational high school (henceforth will be called as SMK) graduates should be able to create productive jobs through entrepreneurship. Therefore, the young generation is expected to be able to see the opportunities to channel their potentials to become successful entrepreneurs (Susianna, 2007). Furthermore, the job world is shifting. Small companies often become the main source of jobs, thus, changes the job pattern (Kuratko \& Hodgetts, 2004). This shift has boost demand on entrepreneurship education. The SMK graduates enter the job world where the majority of new jobs are created by small and medium enterprises. Restructuring and downsizing of companies are an additional force to increase the birth of new business startups (Lord, 1999). SMK students may need to plan to become entrepreneurs as alternative carriers in the changing job market. This development creates entrepreneurship opportunity which demands creative and competent entrepreneurs.

Prior to one's making decision to further exploit an opportunity, that person will develop a psychological intention to determine whether or not to exploit that opportunity is an appropriate and wanted choice. Therefore, entrepreneurship intention is considered as an essential construct as intended to create his or her own business generally an important step in a process to become 
an entrepreneur, and that intention is a strong determinant for planned behavior (i.e., Bird, 1988; Krueger et al, 2000; Zhao, Seibert, \& Lumpkin, 2010). The intention has practical and theoretical implication to determine the success of entrepreneurship as to initiate purposeful activity needs quality and genuine ideas. Businessmen tend to have an optimistic attitude, intention to take risks, leadership, energetic in their efforts to achieve objectives, and make it their personal responsibility to achieve success (Kuratko \& Hodgetts, 2004; McClelland, 1961), which direct to entrepreneurship activities (Lumpkin \& Dess, 1996). SMK students have similar characteristics and potential as they are drawn to have entrepreneurship as a carrier. The essential quality may be different than to prepare those who will work in organization or companies. The success is heavily relied on how individual process information (Krueger, 2000). Students need to show several levels of planned intention toward their chosen carrier paths. Identification of their suitability with entrepreneurship may enable them to formulate coherence and strategic intention to explore and guide them through stages planed in the future. Intention lays on the enter of strategic planning and competency (Krueger \& Brazeal, 1994). Before acting on the selected carrier as entrepreneurs, students need to see and reflect on opportunities that are open to them. One's ability to understand the alternative entrepreneurship can increase their chance to identify satisfying carrier path.

The fact shows that only a small portion of SMK graduates that pursue higher education and quite large proportion of them are still jobless. On the other hand, they are expected to be able to create new jobs from the skill that they have been trained on and work independently as entrepreneurs. The lack of interest to work as entrepreneurs on SMK students may due to their doubts and fear of failure, hence, they are not ready to face the challenges of becoming entrepreneurs. Therefore, only those who dare to take risks and have sufficient courage to face the challenges which have high intention to become entrepreneurs. Creating new entrepreneurs needs high emotional intelligence and entrepreneurship selfefficacy. Emotional intelligence is crucial for an entrepreneur. This is due to the constant interaction of an entrepreneur with others. Emotion should be well managed and controlled for the success of the business. If an entrepreneur cannot control their emotion, and it is directed to negative things, then, it may bring an unwanted result for the business (Huda, 2006). Whereas, entrepreneurship selfefficacy will bring a maximum result when a student is confident of himself/herself to be successful as an entrepreneur. However, it is a common knowledge that not all students have high entrepreneurship self-efficacy Students often fear the risk of failure that won't be manageable. Entrepreneurship self-efficacy can be a barometer of one's intention toward something that she/he believes in. Starting up a new business would need one's faith in his/her ability to develop his or her business. When one has no self-efficacy, it is unlikely for that person to have good attitude in business. Entrepreneurship attitude should be available even before a student decided to become an entrepreneur. Further, it will make them commit to their decision. This attitude also helps students in their further activities.

Human's actions are always supported by certain factors to achieve certain objectives. There is no human activity that has no purpose. This is also applied for entrepreneurship, where human needs motivation to act. Wiratno (1996) 
proposed that an entrepreneur is brave enough and is a leading figure in business, in other words, an entrepreneur is a person who is willing to take risks, creative, and can become a good example in business, a person who works to the best of his/her ability. Entrepreneurship is a process to create something of better value by using the time and creativity, taking the financial, psychological and social risks that come with it, and accept monetary reward and personal satisfaction for those efforts.

Morris (2006) defines entrepreneurship as a process to create value through a combination of unique resources and taking the available opportunities. He further describes it as a different way of thinking and way of action. From this perspective, entrepreneurship is a planned behavior. Entrepreneurship can be conceptualized as a process where individual shows innovative, proactive and risktaking characters in making strategic decisions (Morris, 1998; Weerawardena, 2003). This process needs to be developed for SMK students to prepare them for the ever-changing job market and technology. A businessman or an entrepreneur has to have emotional intelligence in achieving their objectives. Emotional intelligence according to Daniel Goleman is a plus ability of a person in motivating himself/herself, endurance in facing failure, managing emotion, and postponing satisfaction as well as managing the state of mind (Goleman, 1996:45) whereas, Sawaf (2002:15) stated that emotional intelligence is an ability to feel, understand, and effectively implement emotional power and sensitivity as a source of energy, information, connection, and humanly influence. Emotional intelligence demands its owner to learn to acknowledge, respect their own feeling and others and responds appropriately toward those feelings and effectively implement that positive energy in their daily lives.

Human acts based on the stimulus from its environment, including their self-efficacy that they are able or unable to do something. This belief will bring changes to the environment after the human acts. King 2010: 412) wrote that selfefficacy is an individual's belief that he or she can manage a situation and produce a positive outcome from it. The influence of the existence of self-efficacy will make a person have good habits. According to Alwisol (2008: 287), self-efficacy is an individual perception of himself/herself on how good she/he can function in a certain situation. Self-efficacy is related to the belief that he/she has the ability to perform expected actions. Self-efficacy depends on each person; it can be beliefs that she/he can do positive or negative things. Self-efficacy is different from a dream. The dream is something that should be achieved, while self-efficacy is the self-judgment on self-ability.

According to Bandura (Feist \& Feist, 2011: 212), self-efficacy is one's belief in their ability to control his/her functions in the environment. Having self-efficacy is important for every human being. Self-efficacy encourages someone to understand the situation that they are currently facing, in addition, to be able to describe why she or he fails or success in something. Establishing attitude and mental of an entrepreneur is crucial, considering the entrepreneurship attitude is a substantive foundation and evaluative response toward entrepreneurship aspects, especially toward business-oriented activities. Those who have entrepreneurship attitude have several strong characteristics such as, strong willingness to achieve the target and fulfill life needs, have strong faith and self-efficacy, honest and 
responsible, have physical and mental resilience, persistent and diligent in work, have creative and constructive thoughts, future-oriented, and willing to take the risk. According to Suharyadi (2007:10) that one's entrepreneurship attitude can be observed from their daily activities, where they are: discipline, have the high commitment, honest, creative, innovative, and independent. There are several factors that influence the establishment of attitude such as, personal experience, culture, other important figures, and an emotional factor of an individual (Azwar, 2007:30).

\section{METHOD}

The subject in this research is students of SMK in Mojokerto regency. The samples were taken using purposive sampling, resulting in 169 samples. The data analysis used in this study is Structural Equation modeling correlation in Smart PLS statistical program. The causality correlation among variables in this study is described as follow.

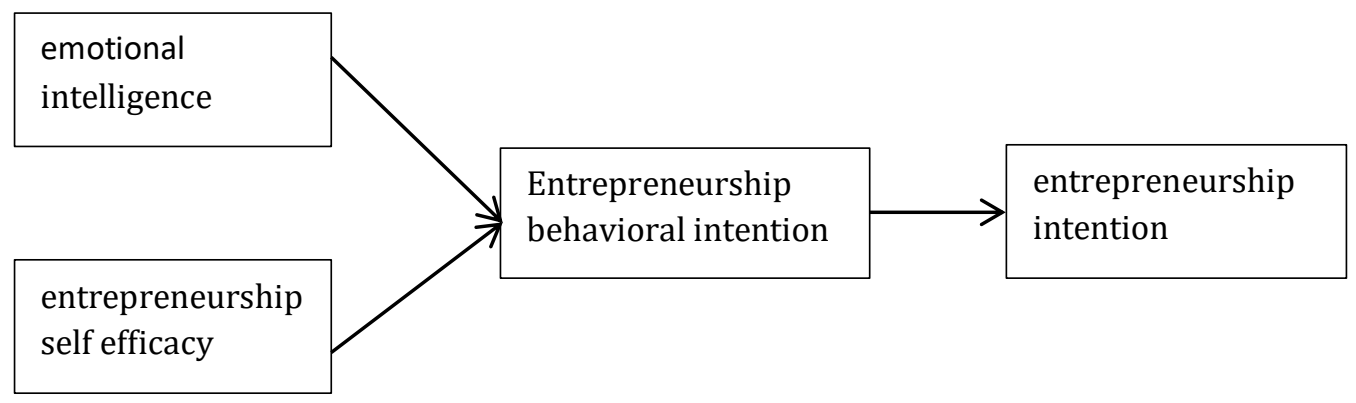

Figure 1. Research Model

\section{RESULTS \& DISCUSSION Results}

This study used the partial least square (PLS) model for its statistical test. In general, the measurement of the model consists of testing the measurement model and the structural model. The following is the statistical testing result with PLS method. Implementation of measurement in PLS to test the validity of the construct and reliability of the instrument. A validity test of the data in this study used PSL software with an outer model of convergent validity that can be seen from average variance extracted (AVE) from each construct where more than 0.5 value is considered to have good discriminant validity.

Table 1. Average Variance Extracted (AVE)

\begin{tabular}{lc}
\hline & AVE \\
Entrepreneurship behavioral intention & 0,535 \\
Emotional intelligence & 0,553 \\
Entrepreneurial self-efficacy & 0,599 \\
\hline
\end{tabular}

Table 1 describes that the value of AVE from emotional intelligence dimension, entrepreneurial self-efficacy, entrepreneurship behavioral attitude. It 
shows that each variable has AVE value above 0.5 . It means that each variable has a good validity of each indicator in the questionnaire used to find out the influence of emotional intelligence and entrepreneurial self-efficacy toward the entrepreneurship behavioral attitude and entrepreneurship intention and the influence of entrepreneurship behavioral attitude toward the entrepreneurship intention are stated as valid.

The PLS software is also used to test the reliability of the instruments by using the composite reliability. An instrument is said to be reliable when it has the composite reliability of more than 0.7 .

Table 2. Composite Reliability

\begin{tabular}{lc}
\hline & Composite Reliability \\
\hline Entrepreneurship behavioral intention & 0.920 \\
Emotional intelligence & 0.925 \\
Entrepreneurial self-efficacy & 0.931 \\
\hline
\end{tabular}

Table 2 showed that each variable has the composite reliability of more than 0.7, which indicated that the internal consistency of independent variable (entrepreneurship behavioral attitude and entrepreneurship intention) and dependent variables (emotional intelligence and entrepreneurial self-efficacy) have good reliability. There are three criteria in testing the outer model in PLS, one of them is through testing the convergent validity, whereas the other two criteria have been discussed above (Discriminant Validity in the square root of average variance extracted (AVE) and Composite Reliability). For convergent validity testing of a measurement model with indicator reflection is tested based on the correlation between item score/component score estimated using the PLS software. Individual reflective measurement is said to be high when the correlation of the tested variable is more than 0.7. However, according to Chin in Ghozali (2006), for initial stage development, the measurement scale of loading value of 0.5 to 0.6 is considered sufficient.

The data measurement from SmartPLS software where the value of outer loadings of variable indicators for emotional intelligence and entrepreneurial selfefficacy showed that there was no value below 0.5 and showed that overall; the correlation with variables had met the convergent validity. This was also shown in the t-statistical value of each indicator whose value is larger than t-count (1.96). The validity test for independent variable concludes that emotional intelligence variable and entrepreneurial self-efficacy variable have met the discriminant validity.

The data analysis through Smart PLS software where the outer loadings value of entrepreneurship behavioral attitude indicators revealed that there was no value below 0.5 and showed the value of outer model or correlation with overall variable had met the convergent validity. This is also shown in the value of t-statistic for entrepreneurship behavioral attitude indicators that showed the value that is larger than t-count (1.96), hence, it is concluded that the entrepreneurship behavioral attitude variable has met the discriminant validity standard. 


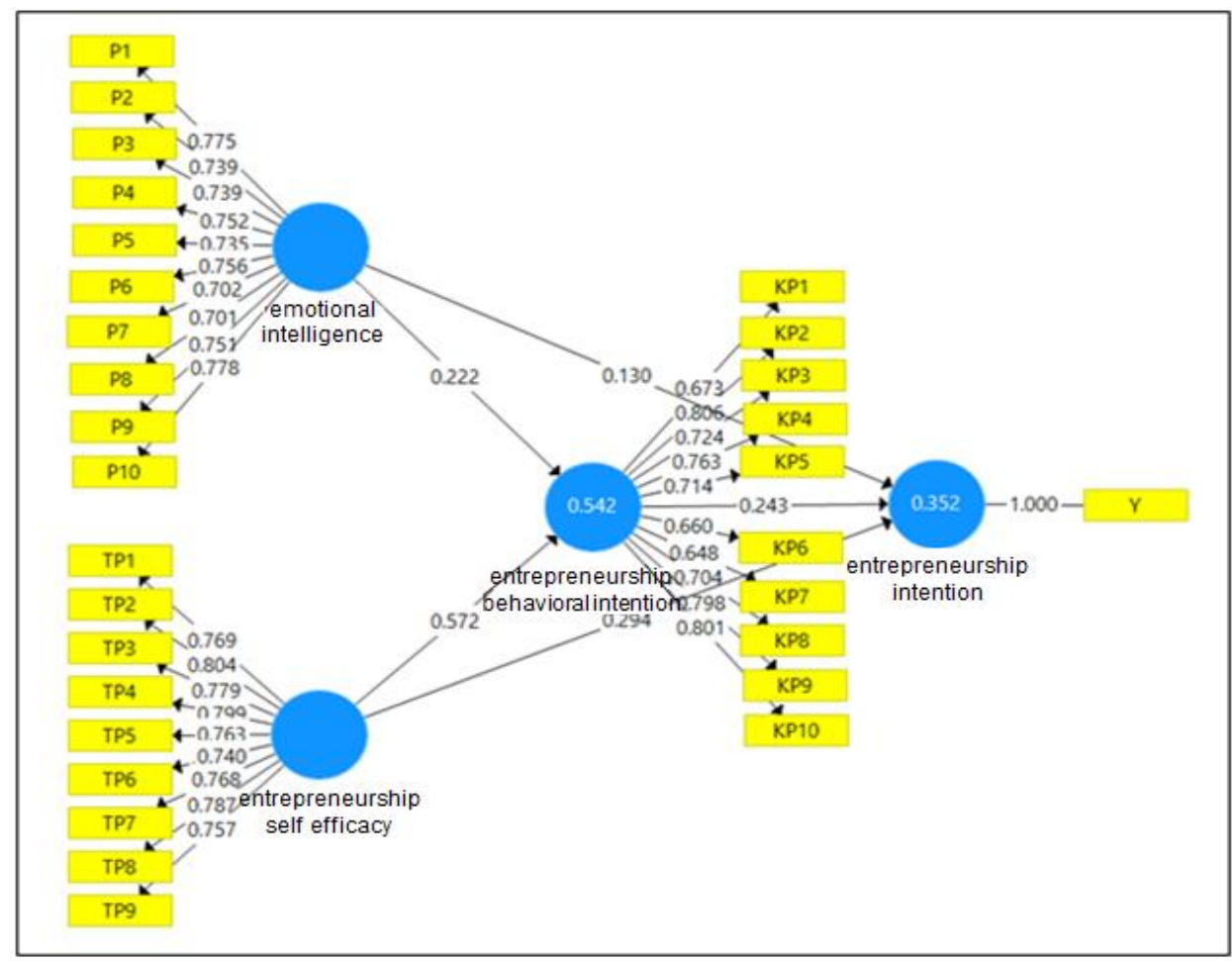

Figure 2. Model Structural Partial Least Square

The output of the estimated structural model is presented in the Table 3.

Table 3. Results for inner weights

\begin{tabular}{lccccc} 
& $\begin{array}{c}\text { Original } \\
\text { Sample (0) }\end{array}$ & $\begin{array}{c}\text { Sample } \\
\text { Mean (M) }\end{array}$ & $\begin{array}{c}\text { Standart } \\
\text { Error } \\
\text { (STERR) }\end{array}$ & $\begin{array}{c}\text { T Statistics } \\
\text { (O/STERR) }\end{array}$ & P Values \\
\hline $\begin{array}{l}\text { Emotional intelegence - } \\
\text { > entrepreneurship } \\
\text { behavioral intention }\end{array}$ & 0.222 & 0.228 & 0.067 & 3.292 & 0.001 \\
$\begin{array}{l}\text { Entrepreneurship self } \\
\text { efficacy -> } \\
\text { entrepreneurship } \\
\text { behavioral intention }\end{array}$ & 0.572 & 0.571 & 0.065 & 8.752 & 0.000 \\
$\begin{array}{l}\text { Emotional intelligence - } \\
\text { >ntrepreneurship }\end{array}$ & 0.130 & 0.129 & 0.085 & 1.537 & 0.125 \\
$\begin{array}{l}\text { intention } \\
\begin{array}{l}\text { Entrepreneurship self } \\
\text { efficacy -> }\end{array}\end{array}$ & 0.294 & 0.288 & 0.126 & 2.326 & 0.020 \\
entrepreneurship & & & & & \\
$\begin{array}{l}\text { intention } \\
\text { Entrepreneurship } \\
\text { behavioral intention -> } \\
\text { entrepreneurship } \\
\text { intention }\end{array}$ & 0.243 & 0.252 & 0.112 & 2.171 & 0.030 \\
\hline
\end{tabular}

The significance of measured parameters provides important information on the correlation of investigated variables. The hypothesis is tested based on the value of output result for inner weight. The following is an overall correlation of 
variables that stated the influence of emotional intelligence and entrepreneurial self-efficacy toward entrepreneurship behavioral intention and entrepreneurship intention; and entrepreneurship behavioral intention toward the entrepreneurship intention of SMK students in Mojokerto regency.

In PLS calculation or statistical estimation of each correlation hypothesized in the study is conducted through simulation through a bootstrap method in each sample. This bootstrap testing is also intended to minimize abnormality of the research data. The result of the bootstrapping test from PLS analysis is presented as follow. The Influence of emotional intelligence has a direct and positive correlation with entrepreneurship behavioral attitude. The first hypothesis testing showed that the correlation of emotional intelligence variable with entrepreneurship behavioral attitude showed the path coefficient value of 0.222 with the $t$-count value of 3.292. This value is larger than the t-table (1.96) and the p-value of 0.001 which was smaller than 5 percent $(\mathrm{P}<0.05)$. This means that emotional intelligence has a positive and significant correlation with entrepreneurship behavioral attitude which agrees with the first hypothesis where it was stated that emotional intelligence has an influence on entrepreneurship behavioral attitude.

The influence of entrepreneurial self-efficacy has a direct and positive correlation with entrepreneurship behavioral attitude. The testing on the second hypothesis showed that the correlation between entrepreneurial self-efficacy showed the path coefficient value of 0.572 with the t-count value of 8.752 . This value is larger than the t-table value (1.960) and the $P$ value of 0.000 which was smaller than 5 percent $(\mathrm{P}<0.05)$. This means that entrepreneurial self-efficacy has a positive and significant correlation with entrepreneurship behavioral attitude, which backs up the second hypothesis, where it was stated that entrepreneurial self-efficacy influences entrepreneurship behavioral attitude.

Emotional intelligence has a direct and positive correlation with entrepreneurship intention. The result of the third hypothesis testing showed that the correlation between emotional intelligence variable and the entrepreneurship intention showed the path coefficient value of 0.130 with the $t$ count value of 1.537. This value was smaller than the t-table value (1.960) and a p-value of 0.125 which was larger than 5 percent $(\mathrm{P}>0.05)$. This means that the emotional intelligence has a positive but insignificant influence toward entrepreneurship intention, which disagrees with the third hypothesis, where it was stated that emotional intelligence has an influence toward entrepreneurship intention.

The result of the fourth hypothesis testing showed that the correlation between entrepreneurial self-efficacy variable and entrepreneurship intention showed the path coefficient value of 0.294 with the $t$ count value of 2.326 . This value was larger than the t-table value (1.960) and the $p$-value of 0.020 which was smaller than 5 percent $(\mathrm{P}<0.05)$. This means that entrepreneurial self-efficacy has a positive and significant correlation toward entrepreneurship intention which backs up the fourth hypothesis where it was stated that entrepreneurial selfefficacy influences entrepreneurship intention.

The result of the first hypothesis showed that there is a correlation between entrepreneurship behavioral attitude with the entrepreneurship intention which showed the path coefficient value of 0.243 with $t$ count value of 
2.171. This value is larger than the t table (1.960) and a p-value of 0.030 which was smaller than 5 percent $(\mathrm{P}<0.05)$. This means that entrepreneurship behavioral attitude has a positive and significant correlation with entrepreneurship intention which agrees with the fourth hypothesis where it was stated that entrepreneurship behavioral attitude has influence toward entrepreneurship intention.

This present study is aimed at testing the empirical model that describes the correlation between emotional intelligence, entrepreneurial self-efficacy toward the entrepreneurship behavioral attitude and entrepreneurship intention. Based on the criteria of the strength of the model or R-square, the proposed model was able to describe the correlation of the variables properly. The structural model in PLS is evaluated using the R-square for dependent variables. This R-square value is used to determine the level of independent variable variation toward the dependent variable. The higher the R-square value, the better the prediction of the model in the research. The result of R-square calculation through Smart PLS software is presented in the table below.

Table 8. R-Square

\begin{tabular}{lc}
\hline & R square \\
\hline Entrepreneurship behavioral attitude & 0.352 \\
Entrepreneurship intention & 0.542 \\
\hline
\end{tabular}

The extent of the influence of each variable toward the other variable can be seen from the R-square which derived from the goodness fit model test which tested the structural model (the inner model). For the influence of emotional intelligence and entrepreneurial self-efficacy toward the entrepreneurship behavioral attitude has the R-square value of 0.338 . This can be interpreted that the variability of the entrepreneurship behavioral attitude was $35.2 \%$ and the rest $64.8 \%$ is described by another variable outside this research. Whereas the influence of emotional intelligence, entrepreneurial self-efficacy, and entrepreneurship behavioral attitude toward entrepreneurship intention has the R-square value of 0.542 . This means that the variability of the entrepreneurship intention was $54.2 \%$ and the rest $45.8 \%$ is described by another variable outside this research.

\section{Discussion}

The study conducted by Burch et al. (2013) created a model of effective entrepreneurship to integrate emotional theory with entrepreneurship. This successful integration showed that emotional approach toward entrepreneurship is promising. Research finding also showed that intelligence is related to the result of entrepreneurship (Baum \& Bird, 2010).

Carmeli (2003) showed that emotionally intelligence individual could consistently experience the positive feeling, whereas those with low emotional intelligence tend to experience angry emotion, depression, and disappointments. Tram and O'Hara (2006) explained that emotionally intelligence individuals are stronger and more skilled in evaluating and controlling their emotion. They can better understand the cause of stress and develop a plan to overcome negative 
results than those with low emotional intelligence. Kafetsios and Zampetakis (2008) showed that utilization of emotion and being aware of one's emotion that related to the emotional intelligence help people to control stress and negative emotion.

The findings in this study showed that individual with high emotional intelligence tends to select entrepreneurship in their carrier orientation. Hence, they constantly scan the environment for opportunities and make use of those opportunities. Therefore, emotional intelligence is described as entrepreneurship disposition (Fuller Jr. \& Marler, 2009). Individuals with high emotional intelligence tend to feel more competent in pursuing entrepreneurship carrier opportunities (Fuller Jr. \& Marler, 2009). This is supported by the fact that entrepreneurship carrier needs a process to identify and exploit its opportunity (Shane \& Venkataraman, 2000). The Consortium for Entrepreneurship Education (2004) insisted that entrepreneurship education can positively influence students in postschool education in many ways. The result of entrepreneurship education in school encompasses the changes in attitude and personal intention and carrier. The potential benefit of entrepreneurship education for students, such as changes in attitude toward entrepreneurship, establishing self-efficacy, personal responsibility or self-management, motivation, problem-solving, creativity, and skill in a business startup are several benefits of entrepreneurship education. The challenges for an education program in the vocational school are to utilize the theoretical framework that can increase students' entrepreneurial self-efficacy to create positive entrepreneurship behavioral attitude. Sustainable process in increasing students' self-efficacy can influence life quality in many ways, including personal and business decision, contribution and leadership in the community, decision making regarding the resources, and maximizing the expected results. Several studies on the correlation between willingness felt, suitability felt, intention to act, and intention (Shapero, 1982) showed that there is a gap of literature on theory based on knowledge of entrepreneurship intention, behavior, and attitude toward entrepreneurship, and intention. This present study discusses this gap of theoretical intention within the context of students in their initial stage of education. This is a stage where students can be expected to make a critical decision on study program intended to lead them to their intended profession.

Based on theory, the emotionally intelligent individual has more suitability to become entrepreneurs and is more possible to become entrepreneurs as they are able to manage their emotion and stress and can quickly recover from negative feelings, as well as managing their emotion during the process of starting up a new business. In addition, as emotionally intelligent individuals have positive attitude influence (Kong \& Zhao, 2013) it is more possible for them to interpret things positively to identify opportunities and become optimistic on the prospect of running their business venture (Baron, 2008). According to emotional intelligence model (Mayer et al., 2003) emotional intelligence refers to one's capacity to (1) fell emotion, (2) utilize that emotion to facilitate thoughts, (3) understand emotion, and (4) manage emotion. Individual with a baseline of depth half-positive emotion in average can quickly come back to positive emotion after experiencing disturbing experience, whereas those with a baseline of depth half-negative emotion tend to experience more frequent negative emotional feeling (Humphrey, 2013). In 
general, it was agreed that individual with high emotional intelligence has to have a positive attitude to influence and be in half positive of the basic emotional (Kong \& Zhao, 2013). Carmeli (2003) showed that emotionally intelligent individual could consistently experience positive feelings and good welfare, whereas an individual with lower emotional intelligence tends to get angry, depress, and disappointed.

Various model of intention has been developed to try to describe the nature of the process that underlies the intended behaviors. The study showed that the background experience of individuals influences attitude, which in turn influence intention that directs the action or behavior (Shapero, 1982). Selfefficacy is a special task to be developed and broaden in the entrepreneurship field (Chen et al., 1998). Entrepreneurial self-efficacy is a strength that based on one's belief in himself/herself that he or she can do the roles and tasks of an entrepreneur. This is an important describing variable to shape the entrepreneurship intention and possibly entrepreneurship actions (Boyd \& Vozikis, 1994). Entrepreneurship environment that full of opportunity for students with entrepreneurial self-efficacy, as well as full of risks and costs for those with low entrepreneurial self-efficacy. When facing the risky, uncertain, and challenging situations, individuals with high entrepreneurial self-efficacy tend to feel more able to overcome them. Individuals with high entrepreneurial self-efficacy have higher possibility to enter entrepreneurship environment than those with lower entrepreneurial self-efficacy.

Students' self-efficacy refers to their ability to imagine, purposefully think, and work with others to initiate changes to create a proper business (Kuratko \& Hodgetts, 2004). Students who dream to be entrepreneurs also can consider themselves as dynamic people with the ability to envision and start the proper business project. Positive perception of the ability to facilitate innovation and interpret it into business activity can influence the entrepreneurship intention (Kuratko \& Hodgetts, 2004). Successful entrepreneurs are those who take the initiative, resilient, have the high commitment, and try new things for productive purposes (Duke, 1996). Students with high self-efficacy consider themselves to have the ability to innovate, set and achieve objectives through their own efforts and it is possible for them to have positive entrepreneurship intention.

The findings in this study can be used by teachers to use this entrepreneurship intention model for vocational students to develop learning activities that targeted the students' behavior and establish their attitude and intention. Teachers can implement this intention model for strategic curriculum decision making such as learning strategy to increase appropriateness perception and willingness to start a business that related to the students' interest. The mission of vocational education to increase the quality of life of the individual and their family rely on the economic development and community development. Vocational education program to increase appropriateness, willingness, intention felt by the students can also increase the entrepreneurship business formation among the community.

One of the assumptions underlying this study is that intention is the center of students' need regarding the study program and their carrier path. The entrepreneurship intention model can increase understanding of the 
entrepreneurship process such as innovation, recognizing opportunity, risk-taking, and proactive (Morris, 1998). Students' understanding of the entrepreneurship process in the initial stage of vocational high school is crucial for them to make informed carrier choice decision. A study that supports this showed that becoming an entrepreneur is an intended and purposeful behavioral process (Krueger et al., 2000).

\section{CONCLUSION}

In order to increase interest to become entrepreneurs for vocational students can be done through the establishment of entrepreneurship behavioral attitude. In addition, students' behavioral intention can also be influenced by emotional intelligence and entrepreneurial self-efficacy. This present study empirically showed that entrepreneurial self-efficacy influences entrepreneurship behavioral attitude, however, emotional intelligence does not have a direct influence on entrepreneurship behavioral attitude. It is recommended for the stakeholder of education, especially SMK education to conduct the evaluation, selection, and orientation of students into study program, carrier program, curriculum development, and learning strategy. An empirical study on the profile of students in this research may be beneficial for students who consider themselves to become entrepreneurs.

\section{REFERENCES}

Alwisol. 2008. Personality Psychology. Malang: UMM Press.

Azwar, S. 2007. Human Attitude, Theory, and its Measurement. Yogyakarta: Pustaka Pelajar.

Baron, R. A. 2008. The Role of Effect in the Entrepreneurial Process. Academy of Management Revie, 33, 328-340.

Baum, J. R., \& Bird, B. J. 2010. The Successful Intelligence of High-Growth Entrepreneurs: Links to New Venture Growth. Organization Science, 21, 397-412.

Bird, B. 1988. Implementing Entrepreneurial Ideas: The Case of Intentions. Academy of Management Review, 13(3), 442-453.

Boyd, N.G., \& Vozikis, G.S. 1994. The Influence of Self-Efficacy on the Development of Entrepreneurial Intentions and Actions. Entrepreneurship: Theory and Practice, 18(4), 63-77.

Burch, G. F., Batchelor, J. H., \& Humphrey, R. H. 2013. Emotional Labor for Entrepreneurs: A Natural and Necessary Extension. Entrepreneurship Research Journal, 3, 331-366.

Carmeli, A. 2003. The Relationship Between Emotional Intelligence and Work Attitudes, Behavior and Outcomes: An Examination Among Senior Managers. Journal of Managerial Psychology, 18, 788-813.

Chen, C. C., Greene, P. G., \& Crick, A. 1998. Does Entrepreneurial Self-Efficacy Distinguish Entrepreneurs from Managers? Journal of Business Venturing, 13, 295-316. 
Duke, C.R. 1996. Exploring Student Interest in Entrepreneurship Courses. Journal of Marketing Education, 18, 35-45.

Feist, J., \& Feist, G. J. 2011. Teori Kepribadian. (Alih Bahasa: Smita Prathiba Sjahputri). Jakarta: Salemba Empat.

Fuller, B., \& Marler, L. E. 2009. Change Driven by Nature: A Meta-Analytic Review of the Proactive Personality Literature. Journal of Vocational Behavior, 75, 329-345.

Goleman, D. 1996. Emotional Intelligence. Jakarta: PT Gramedia Pustaka Utama.

Huda, M. D. 2006. Emosi/emotion. Jakarta: Erlangga.

Humphrey, R. H. 2013a. The Benefits of Emotional Intelligence and Empathy to Entrepreneurship. Entrepreneurship Research Journal, 3, 287-294.

Kafetsios, K., \& Zampetakis, L. A. 2008. Emotional Intelligence and Job Satisfaction: Testing the Mediatory Role of Positive and Negative Affect at Work. Personality and Individual Differences, 44, 712-722.

King, L. A. 2010. Psikologi Umum. (translated: Brian Marwendys). Jakarta: Salemba Humanika.

Kong, F., \& Zhao, J. 2013. Affective Mediators of the Relationship Between Trait Emotional Intelligence and Life Satisfaction in Young Adults. Personality and Individual Differences, 54, 197-201.

Krueger Jr., N. F., Reilly, M. D., \& Carsrud, A. L. 2000. Competing Models of Entrepreneurial Intentions. Journal of Business Venturing, 15, 411-432.

Krueger, N. 2000. The Cognitive Infrastructure of Opportunity Emergence. Entrepreneurship Theory and Practice, 24(3), 5-23.

Krueger, N.F., \& Brazeal, D.V. 1994. Entrepreneurial Potential and Potential Entrepreneurs. Entrepreneurship Theory and Practice, 18(3), 91-103.

Kuratko, D.F., \& Hodgetts, R.M. 2004. Entrepreneurship: Theory, Process and Practice. Mason, OH: Thomson Southwestern.

Lord, M. 1999, March 29. Attention, Aspiring Capitalists; B-school Students are Studying.

Lumpkin, G.T., \& Dess, G.G. 1996. Clarifying the Entrepreneurial Orientation Construct and Linking it to Performance. Academy of Management review, 27(1), 135-172.

Mayer, J. D., Salovey, P., Caruso, D., \& Sitarenios, G. (2003). Measuring emotional intelligence with the MSCEIT V2.0. Emotion, 3, 97-105.

McClelland, D.C. 1961. The Achieving Society. Princeton, NJ: VanNorstand.

Morris, M.H. 1998. Entrepreneurial Intensity Sustainable Advantages for Individuals, Organizations, and Societies. Westport, CT: Quorum.

Morris, M.H. 2006. Some thoughts on teaching issues in Entrepreneurship. A Public Lecture Presented at Lowa State University on January 27, 2006.

Sawaf, A \& Cooper, Robert. 2002. Executive EQ, translated by Widodo. Jakarta: PT Gramedia Pustaka Utama.

Shane, S., \& Venkataraman, S. 2000. The Promise of Entrepreneurship as a Field of Research. Academy of Management Review, 25, 217-226.

Shapero, A. 1982. Social dimensions of entrepreneurship. In C. A. Kent, D. L. Sexton, \& K H.Vesper (Eds.), The Encyclopedia of Entrepreneurship (pp. 72-90). Englewood Cliffs, NJ: Prentice-Hall. 
Suharyadi. 2007. Kewirausahaan Membangun Usaha Sukses Sejak Usia Muda/Entrepreneurship, Building Successful Business from young age. Jakarta: Salemba Empat.

Susianna, N. 2007. Chemical Learning Program to Develop Entrepreneurship Attitude in High School Students. Jurnal Pendidikan (5), 1-10.

Wiratmo, M. 1996. Pengantar Kewiraswastaan/Introduction to Entrepreneruship. Yogyakarta : BPFE, IKAPI. 